\section{In memoriam of \\ Prof. Maria Gabriella Manfredi Romanini}

Prof. Maria Gabriella Manfredi Romanini, Professor Emeritus of the University of Pavia and Honorary Editor of the European Journal of Histochemistry, died in Milan on the last June $6^{\text {th }}, 2010$.

Born in Piacenza on March 25 $5^{\text {th }}, 1924$ she achieved her M.Sc. degrees in Biological Sciences and in Natural Sciences at the University of Pavia, where she began her scientific and academic career under the guide of Prof. Maffo Vialli, pioneer of histochemistry. Consistent with her Mentor's lesson, all along her scientific life she used histochemistry as a tool for investigating in situ cell and tissue biology, in a wide variety of natural and experimental systems, with an inspired and innovative approach.

Her initial scientific interest was focussed on polysaccharides and enzymatic activities in the skin and digestive glands of different Invertebrate and Vertebrate taxa, during development and in the adulthood. In 1992, she was invited to be the editor of the volume "Polysaccharides and glycoconjugates in Invertebrates and non-Mammal Vertebrates" for the series Handbuch der Histochemie.

The most important scientific contribution given by Prof. Manfredi Romanini was, however, the study of the cell nucleus by quantitative histochemistry. Using microphotometry to investigate the relationship between genome size differences and karyotype characteristics in Mammalian species, she demonstrated the role of constitutive heterochromatin in the interspecific differences of genome size; the huge mass of quantitative data collected by prof. Manfredi Romanini and her group in the period 1965-1998 still represents an irreplaceable reference for Primate cytotaxonomy, in particular for the family Lemuridae and for the great apes

The relationships between chromatin superstructural organization and nuclear function was another main topic of prof. Manfredi Romanini's research: for these investigations, she designed the application of multiple histochemical techniques in the attempt to elucidate the role of the different chromatin components in proliferating and kinetically quiescent cell populations in vivo and in culture, and during cell differentiation. She considered "nuclear histochemistry as a real molecular biology in situ, applied to research on dynamic processes in the nucleus, which makes the microscopic and histochemical approach absolutely irreplaceable for the progress of our understanding of cell biology" (Manfredi Romanini M.G., Nuclear histochemistry: its history in fifty volumes. Eur J Histochem 2006; 50:79-81).

Besides her scientific achievements, recognition is due to Prof. Manfredi Romanini for the pivotal role in promoting histochemistry both at national and international level.

Very active member of several Italian and international scientific Societies, she was the President of the Italian Society of Histochemistry from 1998 to 2001. In the period 1980-1983, she established and directed the Postgraduate School of Histochemistry and Cytochemistry at the University of Pavia, where she also organized and headed from 1990 to 2005 the Doctorate in Cytochemistry and Cytomorphology (presently, Doctorate in Cell Biology).

In 1978 she became the Editor of the Rivista di Istochimica Normale e Patologica, the official journal of the Italian Society of Histochemistry: thanks to her firm motivation and tireless efforts, the journal (now European Journal of Histochemistry) increased its scientific reputation and progressed towards its present international readership.

In 1999, in collaboration with the Italian Society of Histochemistry, she established the "Maffo Vialli Award for Histochemistry" which

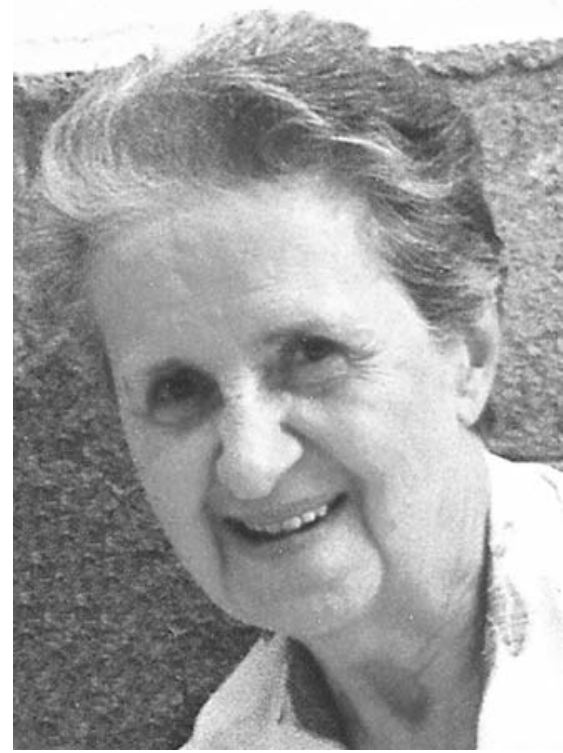

is assigned, every two years, to an individual scientist of international reputation whose work has signified outstanding progress in basic and applied research in cell biology, through any kind of histochemical approach.

Excellent teacher, she was serious, rigorous, and demanding, but at the same time she had the invaluable capability to give her students all what they actually need for their growth, both personally and scientifically: curiosity, passion, motivation, hard working. A great legacy from a true Master.

Prof. Manfredi Romanini has been an indefatigable and outstanding scientist, fascinated and attracted by knowledge, ever combining her enthusiasm with a severe research method and an acute and sharp criticism. But she was also a kind lady, sensitive and charming, able to enrich all her interpersonal relationships with a wide culture and a genuine love for music and arts.

Carlo Pellicciari and Antonio Lauria 